\title{
The Relationship between Staff Attributes and Sharp Practices in the Oil and Gas Down Stream Sector in Nigeria
}

\author{
Rosemary Obasi ${ }^{1} \&$ Chike Nkwor ${ }^{2}$ \\ ${ }^{1}$ Department of Accounting, Benson Idahosa University, Edo State, Nigeria \\ ${ }^{2}$ Mel-Chize-Dek International Limited, Nigeria \\ Correspondence: Rosemary Obasi, Department of Accounting, Benson Idahosa University, Edo State, Nigeria. \\ E-mail: bsrosemary@yahoo.com
}

Received: May 13, 2013

doi:10.5430/rwe.v4n2p54
Accepted: June 19, 2013

Online Published: July 11, 2013

URL: http://dx.doi.org/10.5430/rwe.v4n2p54

\begin{abstract}
We studied the various attributes of the staff of twenty filling stations in Nigeria and related the attributes to sharp practices in the sector. To achieve this purpose, the filling stations' managers, attendants and drivers were interrogated using survey questionnaire. A total of forty staff was sampled. The data collected were analyzed and hypotheses tested using stata 9 soft ware. We find that, experience is critical in reducing sharp practices (ie it is a factor across all the three groups of respondents) in the sector more than any other factor. The age of staff is also important in the reduction of sharp practices, since, it cuts across two of the units of analysis.

We also find that the independent marketers are more into sharp practices than the major marketers $(\mathrm{I} \delta<\mathrm{M} \delta)$. Based on these findings, we conclude that the sector is best run by experienced and aged personnel and our recommendation is that the workers must be adequately remunerated to motivate and distract workers from indulging in sharp practices.
\end{abstract}

Keywords: oil and gas, sharp practices, downstream, petroleum sector

\section{Introduction}

Oil and gas is the lifeblood of the nation's revenue, economy and national survival (Jaiyeoba 2009). It accounts for about $40 \%$ of the gross domestic product and $70 \%$ of government revenues. In 2011, oil and gas accounted for $80.60 \%$ of total federal government receipts. However, the revenue generated from crude oil is being eroded by the activities in the downstream sector through the importation of petroleum products, oil subsidies and a petroleum equalization fund. The economic cost lost to the crude oil subsidy and petroleum equalization fund is $\$ 4.418$ billion, representing about 17.67 percent of Nigeria's annual revenue from crude oil (Odeh, 2011). Meanwhile, MARS (2009) argued that Nigeria's insufficient refining capacity to meet domestic demand, was responsible for the importation of petroleum products. This argument might not be absolutely right because anecdotal evidences have shown that Nigeria businesses are not sustainable. These observations have not been studied empirically in Nigeria.

Nigeria's state-held refineries (Port Harcourt I and II, Warri, and Kaduna) have a combined nameplate capacity of $438,750 \mathrm{bbl} / \mathrm{d}$, but problems including sabotage, fire, poor management and lack of regular maintenance contributed to the operating capacity of about 214,000 bbl/d, as at 2009 (Odeh, 2011). This and the sorry state of disrepair, neglect, and repeated vandalization of petroleum product pipelines and oil movement infrastructure nationwide, corruption, the emergence of a local nouveau riche oil mafia that controls, and coordinates crude oil, products pipeline sabotage and theft (illegal bunkering), diversions of both crude oil and petroleum products, and large-scale cross-border smuggling of petroleum products are the root causes of the protracted, and seemingly intractable severe fuel crises that have bedevilled the country downstream sector with their negative impact on national development (MARS, 2009). The Downstream Gas sector is defined as; "Comprise the activities of transportation, distribution and supply of gas to customers. It includes the extraction of Liquefied Petroleum Gas for commercial purposes and the sale and purchase of gas for industrial purposes such as the production of compressed natural gas, electric power, gas to liquids, liquefied natural gas, methanol and fertilizer, but excludes pipelines for the transportation of natural gas from producing wells to facilities producing Pipeline Specification Gas.” (Gbenga, 2008). 
Otaru (2012) posted on the internet which reported that the Standard Organisation of Nigeria (SON) revealed that, fuel retail outlets in the country have embarked on adulteration of petroleum products in their attempt to make cheap money. Indeed, more than 60 per cent of the over 2,000 retail outlets in Nigeria have kerosene mixed with diesel up to about 77 percent.

Abner, (2011) conducted a field study presented to stakeholders by its Head of Task Force on Petroleum Products (HTFPP), showed that out of the 21 fuel retail outlets in the South West, 15 had up to 69.1 per cent kerosene in diesel. In the Middle Belt, there was presence of kerosene of up to 77.1 percent in the diesel tested, while in the South-South, there was kerosene of up to about 27 percent. Specifically, Abner (2011) disclosed that the diesel available in Enugu State was mostly adulterated with kerosene in all cases except for two stations. He noted that there was also increase of kerosene content in diesel in the Federal Capital Territory (FCT). Even the diesel in SON's power generating set showed kerosene presence of up to 77.1 percent. He added also that, "about six fuel adulteration points between Lagos and the Federal Capital Territory, Abuja, have been uncovered." (Otaru, 2012)

Pipelines and Product Marketing Company (PPMC), a subsidiary of NNPC, has also been accused of involvement in the sharp practices in the downstream sector. The source accused PPMC of supplying adulterated fuel to marketers, saying: "On several occasions, we get adulterated product from PPMC and when we draw their attention to it, they tell us that if we reject the products, there are other marketers who will be willing to take them." This sort of statement shows lack of seller's competition, while buyers are enormous. Although, this allegation was denied by the Director of Department of Petroleum Resources (DPR), Osten Olorunsola, who said the PPMC cannot supply adulterated petroleum products. He argued: "I will tell you that PPMC cannot do such thing, though we may not rule out adulteration of the products by individuals just to indict PPMC" (Otaru, 2012). He further elaborated this claim by reporting that in the month of November, DPR sealed off a total of 96 petrol stations across the country for sharp practices ranging from under delivery of Premium Motor Spirit (PMS), operating without DPR licence or with expired licences to compromising safety and over-pricing and diversion of PMS. The question in the mind now is that, what happened to these stations?

Petroleum and Natural Gas Senior Staff Association of Nigeria (PENGASSAN), accused the federal government of encouraging sharp practices and other unethical activities by operators in the nation's downstream sector of the petroleum industry (Ahiuma-Young, 2008).

According to SON Director-General, Joseph Odumodu, as reported by Opara, (2012), the issue of adulteration of petroleum products has impacted negatively on the socio-economic life of the nation. He, therefore, disclosed the agency's intention to embark on serious monitoring and sanctioning of perpetrators of the illegal business.

Stakeholders in the downstream sub-sector of the petroleum industry have raised the alarm over sharp practices in the sector and their effects on the end-users (consumers). They called for holistic approaches to check the anomalies during the Business Clinic session of the Petroleum Downstream Group of the Lagos Chamber of Commerce and Industry held in Lagos (Vaguard, 2012).

The Director, Department of Petroleum Resources, identified some sharp practices in retail outlet operations in pre-construction, construction and the operation stages. For the pre-construction and construction stage, he said there were cases of false declaration of distance between site and station to qualify for Approval to Construct application, and development of sites different from that which the ATC was granted (that is transfer of ATC while ATC is site-specific).

Olorunshola, who was represented by an Assistant Director at DPR, Mr. Alphonsus Mudei, also noted that at the processing of document stage, the department had observed that doctored photographs of stations were presented to quicken approval of licence. According to him, there are also cases of false certification of pressure/leak test and tank burial reports, as well as falsified declaration of number and capacity of buried tanks.

For operations, he said DPR had observed diversion of products to unauthorised outlets to optimise profits by avoiding mainly government pricing of products. He further asserts, "Station owners are adjusting dispensing pumps thereby under-delivering and illegitimately increasing their product stock and income; they also hoard products with expectation of increase in price; and they intentionally disengage power supply/dispensing pumps to avert checks." (Ahiuma-Young, 2008).

In september 2012, the Department of Petroleum Resources, has warned fuel station operators against sharp practices, saying it would crackdown on stations involved in under-dispensing of petroleum products. Reports have reached the regulators on how filling stations under-dispense products (Vanguard, 2012). 
The department also observed that tanker drivers were using different tank calibration charts to boost the quantity they could load and subsequently siphon and some did not allow products in tanks enough time to settle before gauging by dipping and discharging into receptacles. He added, "We have also seen cases of adulteration of products mostly by increasing the volume of the costlier product with a quantity of a cheaper product.

\section{Research Questions}

To evaluate these claims, we assumed that, the filling stations play more roles in sharp practices. This is because, external influence will end after supply of the products and because we also observed that, some filling stations although few, had un-adulterated products which implies that adulterations take place in the various stations. We therefore structured this study to investigate the various factors responsible for sharp practices in Nigerian filling stations.

Fuel stations in Nigeria are run by individuals. The manager is the one that manages the station; as a result, he can adulterate the product as well as, adjust the dispensing pump. The attendants are responsible for dispensing the products to buyers. Hence, they are capable of under-dispensing or manipulating the meter or dispenser to cheat the buyer. Drivers are also implicated by way of reducing the product while still in transit, ie withdrawing some products before supplying the stations. We assume that employees' characteristics can give insight in explaining the dependent variable. Based on this back drops, the following research question are raised:

\section{RQ1: Do Age, Education, Experience affect sharp practices in Nigeria down stream sector?}

In Nigeria, the down stream sector, especially the marketing of products, is handled by independent individuals who own their stations. They can import products and sell. There are also the Major marketers who are big time dealers in the sector. This group consists of individuals and government. We also assume that since there are two key players in this sector, it will be important to know which of the key players is more into sharp practices in the sector.

\section{RQ2: Will there be difference in the involvement of the oil marketers in sharp practices?}

Based on the foregoing, this study therefore focused on determining the internal factors that are responsible for sharp practices in Nigerian filling stations and suggest ways of implementing government policy/reforms which will strengthen the nation's economy, boosts growth and development. In addition, it will be a catalyst in the achievement of Nigeria's dream of being among the first 20 developed countries in the world by 2020 .

\section{Research Design}

A survey design was adopted through the use of the questionnaire to collect data. Data collected are binary in nature i.e. Yes/No and options responses were elicited. The categories are measured as follows:

1). Yes - 1

$$
\text { No - } 2
$$

2). Types of filling stations

Independent marketers 1

Major marketers 2

3). Age

$\begin{array}{ll}15-30 & 1 \\ 31-40 & 2 \\ 41-60 & 3\end{array}$

4). Education

Primary 1

Secondary 2

NCE 3

Tertiary 4

5). Experience of staff

$$
\begin{array}{ll}
\leq 10 \text { years } & 1 \\
\geq 10 \text { years } & 2
\end{array}
$$


The population of this study is all filling stations in Nigeria. The sample size of the study is twenty filling stations in Nigeria represented as twelve independent marketers and eight major marketers. The stratified sampling method was employed; then the use of random sampling techniques was adopted in the direct selection of the filling stations. The proportional allocation was used to ensure that the subjects from each filling stations type were adequately represented.

The data for this study is primary data source. The use of survey questionnaire to elicit information from filling stations across the nation was adopted. The questions are 9 in number, 3 questions representing demographic data while 6 questions reflect on the attendants, managers and drivers.

To ensure the content reliability and validity of the collection instrument, questions were developed based on careful review of related researches as well as, the corrections and suggestions of filling stations workers who do not form part of this study. Reliability of the instrument, the survey was wide spread across the country; the use of a pre-survey questionnaire to sample experts' opinions was also employed.

Statistical analysis of the data elicited was summarized (i.e. descriptive analysis) and inferential analysis of hypothesis was also conducted. The data collected was analyzed using the stata 9 software. The mean responses for each of the questionnaire items on the various variables will be compared. The t-test statistics was employed to test the hypotheses.

The t-test are parametric statistical tools that can be adopted to test the significance between the proportions, means etc of the unit of analysis opinions. Usually literatures would require the use of t-test for small sample sizes but in situations where a large sample size is available but no population parameters, then the t-test can be a substitute. This is usually denoted as;

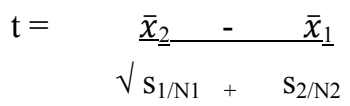

Where;

$$
\begin{array}{lll}
\bar{x}_{2} & = & \text { mean of group two opinions } \\
\bar{x}_{1} & = & \text { mean of group one opinions } \\
\mathrm{S}_{2} & = & \text { standard deviation of group two } \\
\mathrm{S}_{1} & = & \text { standard deviation of group one } \\
\mathrm{N}_{1} \& \mathrm{~N}_{2} & = & \text { no if respondents from each group } \\
\alpha & = & \text { level of significance. }
\end{array}
$$

For test of zero correlation, we adopted the following;

tcal $=\mathrm{r} \sqrt{ } \mathrm{n}-2 / 1-\mathrm{r}^{2}$

$5 \%$ level of significance was used and the degree of free for the t-test is

$\left(\mathrm{n}_{1}+\mathrm{n}_{2}-2\right.$ for two group test).

The decision rules;

Reject the $\mathrm{H}_{\mathrm{o}}$ and accept the $\mathrm{H}_{\mathrm{a}}$ if $(\mathrm{z}<-\mathrm{z} \alpha / 2 ; \mathrm{z}>\mathrm{z} \alpha / 2 ; / \mathrm{z} />\mathrm{z} \alpha / 2, \& \mathrm{t}<-\mathrm{t} \alpha / 2, \mathrm{n}-1 ; \mathrm{t}>\mathrm{t} \alpha / 2, \mathrm{n}-1 ; / \mathrm{t} />\mathrm{t} \alpha / 2, \mathrm{n}-1)$.

\section{Data}

Three categories of workers in the filling station formed the study's respondent's size. Below table shows the units analyzed.

Table 1. Number of staff of the sampled filling stations

\begin{tabular}{lccl}
\hline & INDEPENDENT MARKETER & MAJOR MARKETER & $\begin{array}{l}\text { COLUMN } \\
\text { TOTAL }\end{array}$ \\
\hline MANAGER & 12 & 08 & 20 \\
ATTENDANT & 24 & 16 & 40 \\
DRIVER & 12 & 08 & 20 \\
TOTAL & 48 & 32 & 80 \\
\hline
\end{tabular}

Source: Field work (2013) 
Questionnaires were distributed to each of these groups to fill and return. We had hundred percent response rates since, the entire questionnaire distributed were collected back. The population of attendants are more than the others because, there are more of that group in a filling station. Managers are usually one per station while drivers varied but for convenience sake one driver per station was studied.

The data collected were analyzed using descriptive statistics. This is shown below.

Table 2. Descriptive statistics results of the variables

\begin{tabular}{|c|c|c|c|c|c|}
\hline \multirow{11}{*}{ 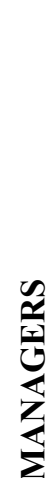 } & VARIABLE & MEASUREMENT & Observation & MODE & $\%$ \\
\hline & \multirow{3}{*}{ Age } & 1 & 18 & \multirow{3}{*}{1} & \multirow{3}{*}{90} \\
\hline & & 2 & 2 & & \\
\hline & & 3 & 0 & & \\
\hline & \multirow{4}{*}{ Education } & 1 & 2 & \multirow{4}{*}{4} & \multirow{4}{*}{50} \\
\hline & & 2 & 6 & & \\
\hline & & 3 & 2 & & \\
\hline & & 4 & 10 & & \\
\hline & \multirow{3}{*}{ Experience } & 1 & 16 & \multirow{3}{*}{1} & \multirow{3}{*}{80} \\
\hline & & 2 & 2 & & \\
\hline & & 3 & 0 & & \\
\hline \multirow{10}{*}{ 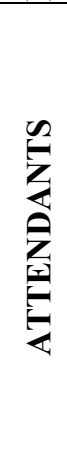 } & & 1 & 20 & \multirow{7}{*}{$\frac{1}{2}$} & \multirow{7}{*}{$\frac{50}{50}$} \\
\hline & & 2 & 18 & & \\
\hline & Age & 3 & 2 & & \\
\hline & \multirow{4}{*}{ Education } & 1 & 8 & & \\
\hline & & 2 & 20 & & \\
\hline & & 3 & 10 & & \\
\hline & & 4 & 4 & & \\
\hline & \multirow{3}{*}{ Experience } & 1 & 38 & \multirow{3}{*}{1} & \multirow{3}{*}{95} \\
\hline & & 2 & 2 & & \\
\hline & & 3 & 0 & & \\
\hline \multirow{10}{*}{$\frac{\tilde{a}}{\frac{\alpha}{x}}$} & Age & 1 & 8 & \multirow{3}{*}{$1 \& 3$} & \multirow{3}{*}{80} \\
\hline & & 2 & 4 & & \\
\hline & & 3 & 8 & & \\
\hline & \multirow[t]{4}{*}{ Education } & 1 & 4 & \multirow{4}{*}{2} & \multirow{4}{*}{60} \\
\hline & & 2 & 12 & & \\
\hline & & 3 & 4 & & \\
\hline & & 4 & 0 & & \\
\hline & \multirow[t]{3}{*}{ Experience } & 1 & 14 & \multirow{3}{*}{1} & \multirow{3}{*}{70} \\
\hline & & 2 & 6 & & \\
\hline & & 3 & 0 & & \\
\hline
\end{tabular}

Source: 2013 Analysis

The table above shows that, the ages of filling stations' managers and attendants range between 15-30 years which is represented by 90 and 50 percents respectively. Drivers are mainly between two ranges ie 15-30 and 41-60 years. The report also shows that, managers are more educated than attendants and drivers (4, 2, and 2 respectively). This implies that, most of the managers are B.Sc holders, while attendants and drivers are basically senior secondary school certificate holders.

Managers have been shown to have the highest years of experience. Most of the managers have more than 10 years of experience while, drivers and attendants both have experiences less than or equal to 10 years.

\section{Test of Hypothesis}

\section{$H_{o l}$ : There is a positive relationship between Age, Education, Experience and income and sharp practice.}

To carry this test, correlation analysis of the variables were conducted and the result is shown on Table 3 below. 
Table 3. The correlation matrix

\begin{tabular}{|c|c|c|c|c|c|c|c|}
\hline \multirow{7}{*}{ 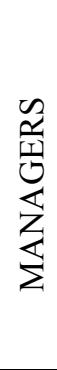 } & VARIABLES & AGE & EDU & EXPR & INCOME & ADULTERATION & $\begin{array}{l}\text { METER } \\
\text { ADJUSTMENT }\end{array}$ \\
\hline & AGE & 1.000 & -0.36 & 0.66 & -0.23 & $-1.00 *$ & $-0.25^{*}$ \\
\hline & EDU & -0.36 & 1.000 & -0.05 & 0.23 & 0.36 & 0.14 \\
\hline & EXPR & 0.66 & -0.05 & 1.000 & 0.04 & $-0.66^{*}$ & $-0.38^{*}$ \\
\hline & INCOME & -0.23 & 0.23 & 0.04 & 1.000 & 0.23 & 0.57 \\
\hline & ADULTERATION & -1.00 & 0.36 & -0.66 & 0.23 & 1.000 & 0.25 \\
\hline & $\begin{array}{l}\text { METER } \\
\text { ADJUSTMENT }\end{array}$ & -0.25 & 0.14 & -0.38 & 0.57 & $-0.25 *$ & 1.000 \\
\hline \multirow{5}{*}{ 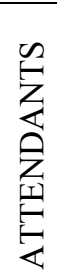 } & & AGE & EDU & EXPR & \multicolumn{3}{|c|}{ ATTENDANT'S MANIPULATION } \\
\hline & AGE & 1.000 & -0.24 & -0.13 & \multicolumn{3}{|c|}{0.27} \\
\hline & EDU & -0.24 & 1.000 & -0.42 & \multicolumn{3}{|l|}{$-0.42 *$} \\
\hline & EXPR & -0.13 & -0.42 & 1.000 & \multicolumn{3}{|l|}{$-0.29 *$} \\
\hline & $\begin{array}{l}\text { ATTENDANT'S } \\
\text { MANIPULATION }\end{array}$ & 0.27 & -0.42 & -0.29 & \multicolumn{3}{|l|}{1.000} \\
\hline \multirow{6}{*}{ 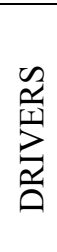 } & & AGE & EDU & EXPR & \multicolumn{2}{|l|}{ NOTPM } & NOSPM \\
\hline & AGE & 1.000 & -0.03 & 0.54 & \multicolumn{2}{|l|}{0.14} & $-0.14 *$ \\
\hline & EDU & -0.03 & 1.000 & -0.58 & \multicolumn{2}{|l|}{-0.18} & 0.18 \\
\hline & EXPR & 0.54 & -0.58 & 1.000 & \multicolumn{2}{|l|}{0.60} & $-0.60^{*}$ \\
\hline & NOTPM & 0.14 & -0.18 & 0.60 & \multicolumn{2}{|l|}{1.000} & $-0.55^{*}$ \\
\hline & NOSPM & 0.14 & 0.18 & -0.60 & \multicolumn{2}{|l|}{-0.55} & 1.000 \\
\hline
\end{tabular}

*Implies reduction in sharp practices.

The correlation result on managers' attributes showed that, age and experience are the variables that can affect sharp practices negatively $(r=-0.25$ and -0.38 respectively), while education and income are positively correlated ( $r=0.14$ and 0.57 respectively) with sharp practices. We therefore tested for significance using the student's t. the result showed that the test statistic value $(\mathrm{t}$ cal $=-1.095)$ exceeds the critical value $\mathrm{t}_{0.025}=-2.048$, so we accept the hypothesis of zero correlation at $\alpha=0.05$.

Attendants result shows that, Education and Experience affect sharp practice negatively $(\mathrm{r}=-0.42$ and -0.29 respectively) while drivers Age, Experience and Number of Trips per month have negative impact on sharp practices $(\mathrm{r}=-0.14,-0.60 \&-0.55$ respectively).

The researchers tested the equality of the marketers' sharp practises using the t- test statistics and below are the result.

$H_{o 2}$ : The sharp practices of independent marketer are equal to those of the major marketers $($ ie $I S P-M S P=0)$.

Table 4. Test for equality of marketers' sharp practises

\begin{tabular}{|c|c|c|c|c|c|c|c|}
\hline MARKETER & VARIABLE & $\mathrm{N}$ & $\mu$ & $\delta$ & tcal & $\mathrm{t} \alpha$ & prob \\
\hline $\begin{array}{l}\text { Independent } \\
\text { Major }\end{array}$ & 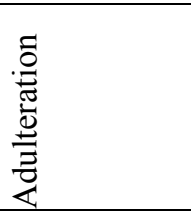 & $\begin{array}{l}12 \\
08\end{array}$ & $\begin{array}{l}1.6 \\
1.6\end{array}$ & $\begin{array}{l}0.55 \\
0.89\end{array}$ & 0.000 & 1.833 & 1.000 \\
\hline $\begin{array}{l}\text { Independent } \\
\text { Major }\end{array}$ & 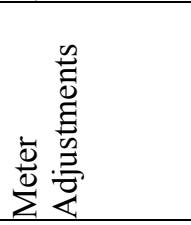 & $\begin{array}{l}12 \\
08\end{array}$ & $\begin{array}{l}1.2 \\
1.2\end{array}$ & $\begin{array}{l}0.45 \\
0.84\end{array}$ & 0.000 & 1.833 & 1.000 \\
\hline $\begin{array}{l}\text { Independent } \\
\text { Major }\end{array}$ & 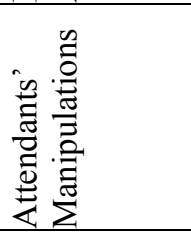 & $\begin{array}{l}12 \\
08\end{array}$ & $\begin{array}{l}1.0 \\
1.0\end{array}$ & $\begin{array}{l}0.00 \\
0.71\end{array}$ & 0.000 & 1.833 & 1.000 \\
\hline
\end{tabular}

Source: 2013 Analysis 
The test of hypothesis has shown that both marketers partake in sharp practises $(t=0.000 ; p 1.000)$ but going by the probability result, we can not certainly say that, the marketers participation in sharp practises are equal. This is justified by the result of standard deviation, which shows the actual variance between the marketers.

\section{Results}

We find that managers and attendants are within the ages of 15 to 30 while, drivers are within the range of 15-60 years. Most Managers are very well educated. They had Bachelor or first degree while the attendants and drivers are basically secondary school holders. Managers had job experiences greater than ten years while, attendants and drivers had less than 10 years experience. The implication of this finding showed that, drivers and attendants do not enjoy working for a long time in filling stations. This could be as a result of little salaries received.

Manager's age and experience affect sharp practices. The result also shows that the more managers adjust the meter the less they adulterate the product. Attendant's education and experience affect sharp practices while, driver's age, experience and number of trips of petroleum products supplied to the filling stations per month affect sharp practices in the down stream sector of the petroleum industry.

Also, we find that, both independent and major marketers have equal interest in sharp practices in the down stream sector. But, the level of interest as shown by the standard deviation result shows that, the independent marketers commit sharp practices more than the major marketers (0.55: 0.89 for adulteration; 0.45:0.84 for meter- adjustment and 0.00: 0.71 for attendant's manipulations respectively). This implies that, the distance between the various offenders in the independent marketers group is very short compared to those of major marketers. Hence, this shows that, independent marketers are more prone to sharp practices than the major marketers.

\section{Recommendations}

Based on the findings, we recommend the following;

$\checkmark$ Managers, attendants and drivers should be remunerated adequately to motivate them well enough to enable them stay longer in the sector, since experience is very important in curbing sharp practices.

$\checkmark$ We also recommend that attendants and drivers be encouraged to further their education, the higher educational qualification they acquire the less the sharp practice.

$\checkmark$ On the alternative, Nigeria should be looking forward to self dispensing system in filling stations as practiced in more developed countries. This recommendation will absolutely curb the problem of sharp practices in this industry a lot.

\section{Conclusion}

This study focused on the factors that determine the involvement in sharp practises in the down stream sector. We surveyed twenty fillings stations in Nigeria, representing twelve independent marketers and eight major marketers. Eighty questionnaires were distributed and eighty were retrieved from the respondents. Based on the research findings, we conclude that the down stream sector of the oil industry in Nigeria partakes in sharp practises and there is no significant difference between the two marketers participation in sharp practices.

\section{References}

Abner, T. (2012). Standards Organization of Nigeria Allege Adulteration of Diesel with Kerosene by Sellers. Retrieved 14 April, 2013, from naijabizcom.com/.../standards-organization-of-nigeria-allege

Ahiuma-Young, V. (2008). Nigeria: PENGASSAN Blames Govt for Sharp Practices in Downstream Oil Sector. Retrieved from allafrica.com/stories/200807010609.html

Gbenga, B. (2008). Investing in Nigeria's Oil and Gas Industry. Retrieved from www.gbclaw.com/investing_in_Nigeria_O andG\%20Industry.pd

Jaiyeoba T. (2009). Investment Opportunities in the Downstream Sector of Nigerian Oil... Retrieved from www.cat.inist.fr/?aModele $=$ afficheN\&cpsidt $=2199280$

MARS. (2009). Research Sector ReportJ... Retrieved from www.marinasecuritieslimited.Com/.../MARS_Research Petroleum_M

Odeh A. M. (2011). Deregulation Policy in the Downstream Oil Sector and the Nigerian Economy. Journal of Social Science and Public Policy, 3, 1-14. Retrieved from www.cenresinpub.org

Opara, S. (2012). Sharp practices in downstream sector worry stakeholders. Retrieved 14 April, 2013, from www.punchng.com $>$ Business $>$ Energy

Otaru, O. (2012). Standards Organization of Nigeria Allege Adulteration of Diesel with Kerosene by Sellers. Retrieved 14 April, 2013, from naijabizcom.com/../standards-organization-of-nigeria-allege

Vanguard. (2012). DPR warns fuel station operators against sharp practices. Retrieved 16 April, 2013, from www.vanguardngr.com 